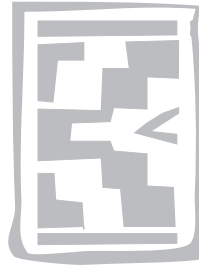

\title{
Report on some monogenean and clinostomid infestations of freshwater fish and waterbird hosts in Middle Letaba Dam, Limpopo Province, South Africa
}

\author{
P.A.S. OLIVIER ${ }^{1 *}$, WILMIEN J. LUUS-POWELL ${ }^{1}$ and J.E. SAAYMAN ${ }^{1,2}$
}

\begin{abstract}
OLIVIER, P.A.S., LUUS-POWELL, WILMIEN J. \& SAAYMAN, J.E. 2009. Report on some monogenean and clinostomid infestations of freshwater fish and waterbird hosts in Middle Letaba Dam, Limpopo Province, South Africa. Onderstepoort Journal of Veterinary Research, 76:187-199

This report deals with the results of a parasitological study done as part of a post-impoundment ecological study of Middle Letaba Dam, Limpopo Province, South Africa. It involved a seasonal survey protocol with particular attention to the diversity and prevalence of the parasitic fauna of the indigenous fish community of the dam and the role of selected fish-eating birds in the life cycle and distribution of fish helminths. The potential species composition of fish of the dam is provided. Monogenean and clinostomatid parasites encountered are listed and infestation statistics of fish and fish-eating bird hosts are presented. The results of this study also provide information on new distribution and host records of the encountered monogeneans.
\end{abstract}

Keywords: Clinostomidae, Middle Letaba Dam, Monogenea, South Africa

\section{INTRODUCTION}

The utilization of freshwater fish to supplement protein demand by humans, especially in rural areas, is a topic widely researched. Nevertheless, South Africa has always lagged behind in this effort when compared to densely populated countries such as China, Taiwan and Israel. Many reasons for this state of affairs can be given, like the customary supply of marine fish from South Africa's long shoreline with its rich, but lately diminishing, fish community. South Africa's inland and rural communities have also not to a large extent developed an established appetite for freshwater fish. This may be due to the

* Author to whom correspondence is to be directed: olivierp@ ul.ac.za

1 Department of Biodiversity, University of Limpopo (Turfloop Campus), Private Bag X1106, Sovenga, 0727 South Africa

2 Present address: 7 Protea Street, Albertinia, 6695 South Africa

Accepted for publication 1 September 2008-Editor relatively effortless and uncomplicated accessibility to competitively priced alternative sources of protein, such as chicken, small ruminants, pigs and cattle.

The position may, however, change drastically. Declining tendencies in marine fisheries output have been reported as long ago as the 1970s (Noble \& Hemens 1978; Cram 1980; Allanson \& Jackson 1983). Since then more documented evidence of this phenomenon is available. The imbalance between the development of land protein resources on the one hand and population growth linked to rising costs of refrigeration and transport of marine protein products on the other, may, however, force the pendulum to move towards utilization of aquaculture products as supplementary food sources. This, together with an increased interest in the development of aquaculture practices, has spurred the initiation of research efforts in aspects such as intensive freshwater fish husbandry, harvesting of fish stocks from natural freshwater habitats (Roode 1978; Saay- 
man 1984; Hecht 1985; Hecht, Uys \& Britz 1988) and the enhancement of guidelines, aims and objectives for aquaculture-supportive research in South Africa (Safriel \& Bruton 1984).

Prioritizing freshwater fish as a supplementary alternative supply of protein for humans indisputably accentuates the importance of fish health in general. In this regard, the significant role of scientific knowledge with regards to indigenous as well as introduced fish parasites can hardly be over-emphasized. Over the last decade the importance of studying fish parasites, including aspects such as their diversity, distribution, infestation rates and pathology have been realized by many South African researchers.

This report deals with the results of parasitological studies done as part of a multidisciplinary research programme on the post-impoundment ecology of the Middle Letaba Dam. The study was commissioned in 1987 by the (then) Department of Development Aid with the Government Service of the (then) Gazankulu Government as beneficiary. The study involved a seasonal survey protocol and particular attention was given to the diversity and prevalence of the parasitic fauna of the indigenous fish community of the dam. Attention also focused on the role of selected waterbirds in the life cycle and distribution of some fish helminths (with special reference to members of the Clinostomidae) using piscivorous birds as final hosts.

\section{MATERIALS AND METHODS}

\section{Study area}

Middle Letaba Dam is situated at $30^{\circ} 24^{\prime} \mathrm{S}, 23^{\circ} 16^{\prime} \mathrm{E}$, about $50 \mathrm{~km}$ west of the city of Giyani, in the Limpopo Province of South Africa. The catchment area of the dam includes two river systems: the Senwabathweni River with a catchment area of $757 \mathrm{~km}^{2}$ and a mean annual rainfall of $757 \mathrm{~mm}$, and the Middle Letaba River with a catchment area of $1042 \mathrm{~km}^{2}$ and a mean annual rainfall of $708 \mathrm{~mm}$. The most important tributaries of these systems are the Koedoes, Brandboontjies and Houtbos Rivers. At full water level, Middle Letaba Dam has a surface area of 1943 ha and a mean depth of $9.5 \mathrm{~m}$ (maximum of $34 \mathrm{~m}$ ). Water temperatures (day and night temperatures) and $\mathrm{pH}$ values were frequently measured at various positions in the dam. Precipitation data were obtained from the Weather Bureau Station in the vicinity of the dam. Water temperatures did not fluctuate much seasonally, with average seasonal day temperatures being $27.5^{\circ} \mathrm{C}$ (autumn), $17.5^{\circ} \mathrm{C}$ (winter), $22^{\circ} \mathrm{C}$ (spring) and $27^{\circ} \mathrm{C}$ (summer) and average night temperatures being $26^{\circ} \mathrm{C}$ (autumn), $16,5^{\circ} \mathrm{C}$ (winter), $20^{\circ} \mathrm{C}$ (spring) and $25.5^{\circ} \mathrm{C}$ (summer). Reasons for these relatively small differences may be due to the fact that the Middle Letaba Dam is situated in a subtropical environment and that at the time of the survey the dam was only about $30 \%$ full. As a result, there was no clear delineation between the epilimnion and hypolimnion resulting in a thorough mixing of the entire water column. For the period of the survey $\mathrm{pH}$ values of the impoundment were relatively constant, with average seasonal values ranging between 7.9 (autumn), 8.3 (winter), 7.7 (spring) and 8.1 (summer).

\section{Procuring and transport of host specimens}

Parasitological surveys were done seasonally from January 1984 to January 1989. The majority of fish hosts were captured using gill nets of various stretched mess sizes, ranging from 30-180 mm but beach seine nets were used in shallower water. Where the physical conditions did not allow the use of gill nets fish hosts were collected by means of electro-fishing. The captured fish were transported live to the field laboratory where they were kept in containers with well aerated water. Avian hosts were shot and their beaks were immediately sealed with elastic bands to avoid the escape of any clinostomid worms lodged in the buccal cavity and oesophagus. The birds were transported in sealed plastic bags to the field laboratory for immediate autopsy and parasitic infestation analysis of the complete alimentary tract.

\section{Examination of hosts for parasites}

Immediately prior to examination, the fish were killed by severing the spinal cord just posterior to the cranium. Monogenean parasites were collected from the gills of the fish with the aid of a stereo microscope and smears were made from the skin and mucosa of the stomach. Sampled monogeneans were fixed in hot $\left(70{ }^{\circ} \mathrm{C}\right)$ alcohol-formalin-acetic acid (AFA) and stored in $4 \%$ buffered formalin. Some of the monogeneans were mounted on microscope slides in glycerine jelly under slight cover slip pressure, and the cover slip sealed with clear nail varnish. Clinostomids were carefully removed from the buccal cavity and oesophagus of the birds, fixed in hot $\left(70{ }^{\circ} \mathrm{C}\right) \mathrm{AFA}$, and preserved in $80 \%$ ethanol. The clinostomids that were collected were mounted on microscope slides for microscopic investigations or stored in $80 \%$ ethanol for further studies. 
Prevalence of infestation (\%) was calculated as the number of infested hosts/number of examined hosts $X 100$. Mean intensity of infestation was calculated as the total number of parasites/number of infested hosts. Standard deviation was not calculated due to meaningless values as a result of too small sample sizes (Rózsa, Reiczigel \& Majoros 2000). For consistency, name changes of hosts since the beginning of this study are incorporated, following that of Skelton (2001) for fish hosts and Hockey, Dean \& Ryan (2005) for bird hosts.

\section{RESULTS AND DISCUSSION}

\section{Fish species composition of Middle Letaba Dam}

A pilot-survey (done prior to the parasitological survey) of the catchment area of the proposed Middle Letaba Dam was carried out to determine the possible species composition of fish which could eventually inhabit the dam (Olivier, Kruger, Van der Waal, Viljoen \& Viljoen 1986). The latter investigation complements a previous study by Gaigher \& McPott
(1973), and mainly correlates with their findings, except for Barbus radiatus Peters and Synodontis zambezensis Peters which the latter authors encountered in the Middle Letaba River and Glossogobius giuris (Hamilton-Buchanan) which they collected at the confluence of the Middle Letaba and Klein Letaba Rivers. Based on the results of these two surveys, the potential fish species diversity of the dam is relatively low, limited to about 28 species with Clarias gariepinus Burchell and Oreochromis mossambicus (Peters) the numerically dominant species (Table 1).

Of the species mentioned in Table 1, Mesobola brevianalis (Boulenger), Opsaridium zambezense (Gilchrist et Thompson), Barbus lineomaculatus Boulenger, B. radiatus, Cyprinus carpio L., Micralestes acutidens (Peters), Amphilius uranoscopus (Pfeffer), Schilbe intermedius Rüppell, Chiloglanis pretoriae Van der Horst, S. zambezensis, Micropterus salmoides (Lacepède), Tilapia rendalli (Boulenger) and G. giuris were not collected from the dam during the present parasitological survey. Some of these may

TABLE 1 Potential species composition of fish of Middle Letaba Dam and its catchment area

\begin{tabular}{|c|c|c|c|}
\hline Gaigher \& McPott 1973 & $n$ & Olivier et al. 1986 & Sampled during this study \\
\hline Anguilla mossambica Peters & 1 & + & + \\
\hline Mesobola brevianalis (Boulenger) & - & + & $\mathrm{x}$ \\
\hline Opsaridium peringueyi (Gilchrist \& Thompson) & - & + & $\mathrm{X}$ \\
\hline Barbus lineomaculatus Boulenger & & + & $\mathrm{x}$ \\
\hline Barbus unitaeniatus Günther & 82 & + & + \\
\hline Barbus bifrenatus Fowler & 13 & + & + \\
\hline Barbus viviparus Weber & 46 & + & + \\
\hline Barbus toppini Boulenger & 68 & + & + \\
\hline Barbus radiatus Peters & - & $\mathrm{x}$ & $x$ \\
\hline Barbus trimaculatus Peters & 89 & + & + \\
\hline Barbus paludinosus Peters & 83 & + & + \\
\hline Labeobarbus marequensis (A. Smith) & 32 & + & + \\
\hline Labeo rosae Steindachner & 24 & + & + \\
\hline Labeo ruddi Boulenger & 64 & + & + \\
\hline Labeo cylindricus Peters & 68 & + & + \\
\hline Labeo molybdinus Du Plessis & 4 & + & + \\
\hline Cyprinus carpio Linnaeus & - & + & $x$ \\
\hline Micralestes acutidens (Peters) & - & + & $x$ \\
\hline Amphilius uranoscopus (Pfeffer) & - & + & $x$ \\
\hline Schilbe intermedius (Rüppell) & - & + & $x$ \\
\hline Clarias gariepinus (Burchell) & 111 & + & + \\
\hline Chiloglanis pretoriae Van der Horst & - & + & $x$ \\
\hline Synodontis zambezensis Peters & - & $x$ & $x$ \\
\hline Micropterus salmoides (Lacepède) & - & + & $x$ \\
\hline Pseudocrenilabrus philander (Weber) & 69 & + & + \\
\hline Tilapia rendalli (Boulenger) & - & + & $x$ \\
\hline Oreochromis mossambicus (Peters) & 177 & + & + \\
\hline Glossogobius giuris (Hamilton-Buchanan) & - & $x$ & $x$ \\
\hline
\end{tabular}

$n=$ number of fish sampled for parasitological analyses

$+=$ species present

$\mathrm{X}=$ species not collected 
still successfully colonize Middle Letaba Dam. However, $C$. pretoriae and $O$. zambezense are considered to prefer rivers as their favoured habitat and will, in all probability, not establish themselves in the dam (Polling, Mokgalong \& Saayman 1983). Synodontis zambezensis and $G$. giuris might also not colonize the dam as they naturally occur only in downstream habitats (Gaigher 1973). The unique construction of the overflow of the dam, forming an impenetrable barrier to upstream migration, will prevent these two species from reaching the dam. Of the 28 species of fish listed in Table 1, only 15 were collected during the parasitological survey and, therefore, could be considered as possible parasite hosts (only a single specimen of Anguilla mossambica Peters was collected during the summer survey of 1984, but revealed no parasites).

\section{Monogenean parasites}

To date, very few records of Monogenea of South African freshwater fish appeared in the published literature (e.g. Paperna 1980; Mashego 1983; Khalil \& Polling 1997; Mashego 2000; Luus-Powell, Mashego \& Khalil 2003; Christison, Shinn \& Van As 2005). During this study monogenean parasites were collected from a total of 831 hosts specimens of as many as 14 different fish species (Table 2).

TABLE 2 Host/parasite checklist of monogenean parasites from Middle Letaba Dam with an indication of host specificity for each species of parasite

\begin{tabular}{|c|c|c|c|}
\hline Host & $n$ & Parasite & $\begin{array}{l}\text { Host } \\
\text { range }\end{array}$ \\
\hline Barbus unitaeniatus Günther & 73 & Dactylogyrus sp. 1 & 3 \\
\hline Barbus bifrenatus Fowler & 13 & Dactylogyrus sp. 4 & 3 \\
\hline Barbus viviparous Weber & 46 & Dactylogyrus sp. 4 & 3 \\
\hline Barbus toppini Boulenger & 68 & Dactylogyrus sp. 4 & 3 \\
\hline Barbus trimaculatus Peters & 70 & $\begin{array}{l}\text { Dactylogyrus afrolongicornis Paperna } \\
\text { Dactylogyrus afrolongicornis alberti Paperna } \\
\text { Dactylogyrus afrosclerovaginatus Paperna } \\
\text { Dactylogyrus allolongionchus Paperna } \\
\text { Dactylogyrus meyersi Price, McClellan, Druckenmiller \& Jacobs } \\
\text { Dactylogyrus sp. } 1 \\
\text { Dactylogyrus sp. } 2 \\
\text { Dactylogyrus sp. } 3\end{array}$ & $\begin{array}{l}1 \\
1 \\
1 \\
1 \\
1 \\
3 \\
2 \\
1\end{array}$ \\
\hline Barbus paludinosus Peters & 83 & $\begin{array}{l}\text { Dactylogyrus dominici Mashego } \\
\text { Dactylogyrus teresae Mashego }\end{array}$ & $\begin{array}{l}1 \\
1\end{array}$ \\
\hline Labeobarbus mareqensis (A. Smith) & 32 & $\begin{array}{l}\text { Dactylogyrus spinicirrus (Paperna \& Thurston) } \\
\text { Dactylogyrus sp. } 1 \\
\text { Dactylogyrus sp. } 2\end{array}$ & $\begin{array}{l}1 \\
3 \\
2\end{array}$ \\
\hline Labeo rosae Steindacher & 24 & $\begin{array}{l}\text { Dactylogyrus sp. } 7 \\
\text { Dactylogyrus sp. } 8 \\
\text { Dactylogyrus sp. } 9 \\
\text { Dactylogyrus sp. } 10 \\
\text { Dogielius sp. } 1\end{array}$ & $\begin{array}{l}2 \\
2 \\
2 \\
2 \\
1\end{array}$ \\
\hline Labeo ruddi Boulenger & 64 & $\begin{array}{l}\text { Dactylogyrus sp. } 7 \\
\text { Dactylogyrus sp. } 9 \\
\text { Dactylogyrus sp. } 9 \\
\text { Dactylogyrus sp. J } \\
\text { Dactylogyrus sp. } 10 \\
\text { Dactylogyrus sp. } 12 \\
\text { Dogielius sp. } 2 \\
\text { Dogielius sp. } 3 \\
\text { Dogielius sp. } 4\end{array}$ & $\begin{array}{l}2 \\
2 \\
2 \\
2 \\
1 \\
1 \\
1 \\
1 \\
1\end{array}$ \\
\hline Labeo cylindricus Peters & 68 & Dactylogyrus sp. 5 & 2 \\
\hline Labeo molybdinus Du Plessis & 4 & $\begin{array}{l}\text { Dactylogyrus sp. } 5 \\
\text { Dactylogyrus sp. } 6\end{array}$ & $\begin{array}{l}2 \\
1\end{array}$ \\
\hline
\end{tabular}


TABLE 2 (cont.)

\begin{tabular}{|c|c|c|c|}
\hline Host & $n$ & Parasite & $\begin{array}{l}\text { Host } \\
\text { range }\end{array}$ \\
\hline Clarias gariepinus (Burchell) & 111 & $\begin{array}{l}\text { Quadriacanthus allobychowskiella Paperna } \\
\text { Quadriacanthus aegypticus El-Naggar \& Serag } \\
\text { Quadriacanthus clariadis Paperna } \\
\text { Quadriacanthus sp. } 1 \\
\text { Quadriacanthus sp. } 2 \\
\text { Quadriacanthus sp. } 3 \\
\text { Quadriacanthus sp. } 4 \\
\text { Quadriacanthus sp. } 5 \\
\text { Quadriacanthus sp. } 6 \\
\text { Quadriacanthus sp. } 7 \\
\text { Quadriacanthus sp. } 8 \\
\text { Quadriacanthus sp. } 9 \\
\text { Quadriacanthus sp. } 10 \\
\text { Gyrodactylus rysavyi Ergens } \\
\text { Macrogyrodactylus clarrii Gussev } \\
\text { Macrogyrodactylus karibae Douellou \& Chishawa }\end{array}$ & $\begin{array}{l}1 \\
1 \\
1 \\
1 \\
1 \\
1 \\
1 \\
1 \\
1 \\
1 \\
1 \\
1 \\
1 \\
1 \\
1 \\
1\end{array}$ \\
\hline Pseudocrenilabrus philander (Weber) & 69 & $\begin{array}{l}\text { Cichlidogyrus tilapiae } \\
\text { Enterogyrus cichlidarium }\end{array}$ & $\begin{array}{l}2 \\
2\end{array}$ \\
\hline Oreochromis mossambicus (Peters) & 105 & $\begin{array}{l}\text { Cichlidogyrus halli (Price \& Kirk) } \\
\text { Cichlidogyrus sclerosus Paperna \& Thurston } \\
\text { Cichlidogyrus tilapiae Paperna } \\
\text { Cichlidogyrus sp. } 1 \\
\text { Cichlidogyrus sp. } 2 \\
\text { Enterogyrus cichlidarum Paperna } \\
\text { Scutogyrus gravivaginus (Paperna \& Thurston) }\end{array}$ & $\begin{array}{l}1 \\
1 \\
2 \\
1 \\
1 \\
2 \\
1\end{array}$ \\
\hline
\end{tabular}

$n=$ number of hosts examined

$1=$ one-host parasite

2 = two-host parasite

$3=$ three-host parasite

Although some of the parasites encountered are of uncertain specific status, their generic status and host distribution were positively verified.

The dactylogyrid species were obtained from the gills of their respective hosts. Gyrodactylid parasites were found to be present on either the skin or the gills of the host. Species of Chichlidogyrus Paperna and Scutogyrus Pariselle \& Euzet are harboured on the gills of their hosts, while Enterogyrus chichlidarum Paperna occurs in the mucosa of the stomach of both its hosts (Pseudocrenilabrus philander (Weber) and O. mossambicus).

During the current study, members of three monogenean families, represented by eight genera and 47 species (19 known species and 28 unidentified species), were encountered (Table 2). Species of these families are known to be variably host specific, with host ranges restricted to one or only a few closely related species. This trend is supported by the results of this study (Table 2 ). In general, members of the genus Dogielius Bikhovski were found only on two of the four Labeo hosts and species of
Quadriacanthus Paperna, Gyrodactylus Paperna and Macrogyrodactylus Malberg were found on $C$. gariepinus only. Species of Cichlidogyrus were restricted to $P$. philander and $O$. mossambicus, while Scutogyrus gravivaginus (Paperna \& Thurston) was collected from O. mossambicus only. Species of the genus Dactylogyrus Diesing are parasites of Barbus and Labeo species. More specifically, Table 2 clearly illustrates the phenomenon of host specificity with no less than 37 of encountered species found on a single host, eight parasitized two-host species and only two were harboured by three different hosts. This corresponds with findings of Mashego (1983) who reported on eight of the parasites collected during the present study parasitizing the same host species, although from different geographical regions in South Africa. These are Dactylogyrus afrolongicornis afrolongicornis Paperna, Dactylogyrus afrolongicornis alberti Paperna, Dactylogyrus afrosclerovaginatus Paperna, Dactylogyrus allolongionchus Paperna and Dactylogyrus meyersi Price, Mclellan, Druckenmiller \& Jacobs from Barbus trimaculatus Peters, Dactylogyrus dominici Mashego 
and Dactylogyrus teresae Mashego from Barbus paludinosus Peters, and Dactylogyrus spinicirrus (Paperna \& Thurston) from Labeobarbus marequensis (Smith, 1841).

In general, the intensity of monogenean infestations was found to be very low, on average five parasites per infested host. However, the diversity of monogeneans on C. gariepinus (with no less than 16 species), with a more profound and variable intensity of infestation, is noteworthy. Immediately after the closure of the dam in 1984, very low intensities were observed (mean intensity $=1.0$ ) followed by a tremendous increase, reaching a peak in the summer of 1986/1987 (mean intensity $=700.0$ ). This was followed by a steady decline to as low as a mean intensity of less than 1.0 in January 1988. The latter could be ascribed to the greater volume of water as a result of good rains in December/January of 1987/ 1988 (more than $250 \mathrm{~mm}$; mean annual for the catchment area is $732 \mathrm{~mm}$ ) resulting in a decline in host density. Gyrodactylids have no free swimming larval stages and infestation between individual hosts is probably by direct contact (Paperna 1980).

During the period of hyperinfestation, infested specimens of $C$. gariepinus all developed a thick layer of greyish-white mucus over the entire skin, in all probability caused by the severe irritation caused by the parasites. Other pathological signs observed included proliferation of epithelial cells at the point of attachment, erosion of the skin and fading of skin colour, all of which are in accord with similar observations reported by Paperna (1980).

Monogeneans encountered from Middle Letaba Dam revealed some species representing either first parasite records, or new host records from South Africa. This can be summarized as follows:

1. Gyrodactylus Von Nordman (Gyrodactylidae). Christison et al. (2005) provides a summary of all the gyrodactylids that have been reported from southern Africa. These include one known, Gyrodactylus transvaalensis Prudhoe \& Hussey, and three unidentified species as records from South Africa. None of the latter was collected during this survey. However, the authors agree with Christison et al. (2005) that the records of the three unidentified species referred to by Bragg (1991) and Lombard (1968), should not be considered as part of the South African fauna due to their association with alien fish hosts (rainbow trout and large mouth black bass, respectively). However, Gyrodactylus rysavyi Ergens, described and reported to date only from
Egypt (Ergens 1973), was encountered during the present study from C. gariepinus, and represents a new distribution record from South Africa.

2. Macrogyrodactylus Malberg (Gyrodactylidae). During this study two macrogyrodactylid species (Macrogyrodactylus clarii Gussev and Macrogyrodactylus karibae Douëllou \& Chishawa) were encountered from $C$. gariepinus and have previously been reported on by Khalil \& Mashego (1998). The latter authors also reported on Macrogyrodactylus congolensis (Prudhoe) collected from C. gariepinus at Mokgoma-Matlala Dam, South Africa.

3. Dactylogyrus Diesing (Dactylogyridae). Eleven dactylogyrid species were previously reported from South Africa (Khalil \& Polling 1997): D. afrolongicornis Paperna, D. afrolongicornis alberti, $D$. afrosclerovaginus, $D$. allolongionchus, $D$. dominici, Dactylogyrus enidae Mashego, Dactylogyrus jubbstrema Price, Korach \& McPott, $D$. myersi, Dactylogyrus pienaari Price, Korach \& McPott and $D$. spinicirrus $D$. teresae Mashego. Of these, only three species, $D$. enidae, $D$. jubbstrema and $D$. pienaari, were not encountered during this study. Of the remaining seven species collected, it is worthwhile to note that $D$. afrosclerovaginus was collected from Barbus trimaculatus Peters (previously reported from Barbus paludinosus Peters), representing a new host record. Additional to the above, 12 unidentified dactylogyrid species were found from six hosts (Table 2).

4. Dogielius Bikhovski (Dactylogyridae). None of the more than 20 described species from Africa (Khalil \& Polling 1997) was either sampled during the present study or is previously known from South Africa. However, four unidentified species, one from Labeo rosae Steindachner and three from Labeo ruddi Boulenger, were collected.

5. Quadriacanthus Paperna (Dactylogyridae). Three formerly described species (Quadriacanthus aegypticus El-Naggar \& Serag, Quadriacanthus allobychowskilla Paperna and Quadriacanthus clariadis Paperna) and ten unidentified species, all sampled from $C$. gariepinus and all being first records for the genus from South Africa, were collected.

6. Chichlidogyrus Paperna (Ancyrocephalidae). Only one species, Chichlidogyrus papernastrema Price, Peebles \& Bamford is previously known 
from South Africa. This species was not collected during the present survey, possibly due to the absence of the type host, Tilapia sparrmanii Boulenger. However, five chichlidogyrid species were encountered and are new records for South Africa: Chichlidogyrus halli (Price \& Kirk), Chichlidogyrus sclerosus Paperna \& Thurston, Chichlidogyrus tilapiae Paperna and two unidentified species.

7. Enterogyrus Paperna (Ancyrocephalidae). Enterogyrus cichlidarum Paperna was the only species collected and represents a first record of the genus from South Africa.

8. ScutogyrusPariselle\&Euzet(Ancyrocephalidae). Scutogyrus gravivaginus (Paperna \& Thurston) was the only species collected and it is a first record of the genus from South Africa.

\section{Digenean species of the family Clinostomidae}

Positive species designation of trematodan metacercariae is usually difficult due to their undifferentiated genitalia, therefore adult stages from the definitive host are frequently the only way to achieve positive identification. However, the fact that most trematodes, including their larval stages, are highly host specific (Paperna 1980; Grobler \& Mokgalong 2002) can be applied as a useful tool for identification. Furthermore, diagnosis during this survey was somewhat easier as trematode infestations (especially that of clinostomids) of resident piscivorous birds acting as definitive hosts, were simultaneously investigated (Mokgalong 1996).

In the past, many problems were experienced with the specific diagnostic designations of members of the family Clinostomidae (Grobler, Mokgalong \& Saayman 1999). Feizullaev \& Mirzoeva (1983) provided some clarity on solving this problem when they synonomized 35 species as one, Clinostomum complanatum (Rudolphi). These included Clinostomum vanderhorsti Ortlepp and Clinostomum tilapiae Ukoli, both of which prompted much discussion, confusion and misidentification. Recent studies using molecular techniques clearly revealed that material previously identified as $C$. tilapiae, found in the gill chambers of $O$. mossambicus, is in fact Neutraclinostomum intermedialis (Lamont) (Grobler et al. 1999; Grobler \& Mokgalong 2002). The demonstration of high host specificity (O. mossambicus as intermediate fish host and the darter, Anhinga rufa (Daudin), as definitive avian host) for $N$. intermedialis (Mokgalong 1996) further supports the view of considering $C$. tilapiae sampled from gill chambers of $O$. mossambicus, as a junior synonym of $N$. intermedialis. This approach is followed for the present report.

During the present survey three species of the family Clinostomidae were sampled from six different fish hosts (Table 3 ). The results concerning these species are discussed separately below and, where applicable, additional data of similar studies from different habitats in South Africa are presented as comparisons.

\section{Neutraclinostomum intermedialis (Lamont)}

This parasite was exclusively procured from the branchial chambers of $O$. mossambicus and, during this study, a total of 379 specimens were collected. A total of 177 fish hosts were examined and showed a prevalence of $48 \%$ and a mean intensity of 4.4 (Table 3). The largest number of hosts were encountered during summer $(n=87)$, with almost $50 \%$ $(n=39)$ represented by smaller fish (total length $<10 \mathrm{~cm}$ ). Fish longer than $30 \mathrm{~cm}$ were virtually absent from this survey, but the data of a single large specimen is nevertheless included in Table 4.

TABLE 3 Species of the family Clinostomidae collected from infested intermediate hosts from Middle Letaba Dam

\begin{tabular}{|l|l|l|l|l|}
\hline Parasite & Host & $\boldsymbol{n}$ & Prev. & Mi. \\
\hline Neutraclinostomum intermedialis (Lamont) & Oreochromis mossambicus (Peters) & 177 & 48 & 4.4 \\
\hline Clinostomum complanatum (Rudolphi) & Barbus unitaeniatus Günther & 82 & 2.4 & 1 \\
& Barbus trimaculatus Peters & 89 & 1.1 & 2 \\
& Labeobarbus marequensis (A. Smith) & 13 & 7.7 & 1 \\
& Pseudocrenilabrus philander (Weber) & 47 & 6.4 & 1 \\
\hline \multirow{2}{*}{ Euclinostomum heterostomum (Rudolphi) } & Oreochromis mossambicus (Peters) & 177 & 24.9 & 2.2 \\
& Clarias gariepinus (Burchell) & 21 & 4.7 & 9 \\
\hline
\end{tabular}

$n \quad=$ number of hosts examined

Prev. = prevalence of infestation (\%)

Mi. = mean intensity of infestation 
Monogenean and clinostomid infestations of freshwater fish and waterbird hosts in Limpopo, South Africa

TABLE 4 Seasonal analysis, per length group (TL. cm) of Oreochromis mossambicus (Peters), for Neutraclinostomum intermedialis (Lamont) infestations in Middle Letaba Dam

\begin{tabular}{|c|c|c|c|c|c|}
\hline Season & $<10 \mathrm{~cm}$ & $10.1-20 \mathrm{~cm}$ & $20.1-30 \mathrm{~cm}$ & $>30 \mathrm{~cm}$ & All size groups \\
\hline \multicolumn{6}{|l|}{ Summer } \\
\hline $\begin{array}{l}\text { Number of hosts examined } \\
\text { Prevalence of infestation } \\
\text { Intensity of infestation } \\
\text { Mean intensity of infestation } \\
\text { Number of parasites collected }\end{array}$ & $\begin{array}{l}39 \\
53.9 \\
1-21 \\
4 \\
83\end{array}$ & $\begin{array}{l}24 \\
45.8 \\
1-7 \\
4.3 \\
47\end{array}$ & $\begin{array}{l}23 \\
13.1 \\
5-20 \\
11.3 \\
34\end{array}$ & $\begin{array}{l}1 \\
100 \\
4 \\
4 \\
4\end{array}$ & $\begin{array}{l}87 \\
41.4 \\
1-21 \\
4.7 \\
168\end{array}$ \\
\hline \multicolumn{6}{|l|}{ Autumn } \\
\hline $\begin{array}{l}\text { Number of hosts examined } \\
\text { Prevalence of infestation } \\
\text { Intensity of infestation } \\
\text { Mean intensity of infestation } \\
\text { Number of parasites collected }\end{array}$ & $\begin{array}{l}2 \\
100 \\
3-4 \\
3.5 \\
7\end{array}$ & $\begin{array}{l}10 \\
80 \\
2-16 \\
5.6 \\
45\end{array}$ & $\begin{array}{l}3 \\
33.3 \\
- \\
8 \\
8\end{array}$ & $\begin{array}{l}- \\
- \\
- \\
-\end{array}$ & $\begin{array}{l}15 \\
73.3 \\
2-16 \\
5.5 \\
60\end{array}$ \\
\hline \multicolumn{6}{|l|}{ Winter } \\
\hline $\begin{array}{l}\text { Number of hosts examined } \\
\text { Prevalence of infestation } \\
\text { Intensity of infestation } \\
\text { Mean intensity of infestation } \\
\text { Number of parasites collected }\end{array}$ & $\begin{array}{l}11 \\
63.6 \\
1-5 \\
2.4 \\
17\end{array}$ & $\begin{array}{l}4 \\
75 \\
4-5 \\
4.3 \\
13\end{array}$ & $\begin{array}{l}25 \\
40 \\
1-17 \\
3.7 \\
37\end{array}$ & $\begin{array}{l}- \\
- \\
- \\
- \\
-\end{array}$ & $\begin{array}{l}40 \\
50 \\
1-17 \\
3.4 \\
67\end{array}$ \\
\hline \multicolumn{6}{|l|}{ Spring } \\
\hline $\begin{array}{l}\text { Number of hosts examined } \\
\text { Prevalence of infestation } \\
\text { Intensity of infestation } \\
\text { Mean intensity of infestation } \\
\text { Number of parasites collected }\end{array}$ & $\begin{array}{l}18 \\
55.6 \\
1-10 \\
5.5 \\
55\end{array}$ & $\begin{array}{l}14 \\
50 \\
1-9 \\
4 \\
28\end{array}$ & $\begin{array}{l}3 \\
33.3 \\
- \\
1 \\
1\end{array}$ & $\begin{array}{l}- \\
- \\
- \\
- \\
-\end{array}$ & $\begin{array}{l}35 \\
51.4 \\
1-10 \\
4.7 \\
84\end{array}$ \\
\hline \multicolumn{6}{|l|}{ All seasons } \\
\hline $\begin{array}{l}\text { Number of hosts examined } \\
\text { Prevalence of infestation } \\
\text { Intensity of infestation } \\
\text { Mean intensity of infestation } \\
\text { Number of parasites collected }\end{array}$ & $\begin{array}{l}70 \\
57.1 \\
1-21 \\
4.1 \\
16\end{array}$ & $\begin{array}{l}52 \\
55.8 \\
1-16 \\
4.6 \\
133\end{array}$ & $\begin{array}{l}54 \\
27.8 \\
1-20 \\
5.6 \\
80\end{array}$ & $\begin{array}{l}1 \\
100 \\
4 \\
4 \\
4\end{array}$ & $\begin{array}{l}177 \\
48 \\
1-21 \\
4.5 \\
379\end{array}$ \\
\hline
\end{tabular}

The highest prevalence ( $57.1 \%$ for all seasons) was found within the $<10 \mathrm{~cm}$ length group with a $63.6 \%$ registered for the winter survey within the same length group (the autumn survey was not taken into account due the fact that only two hosts were examined). The lowest prevalence was found for hosts of $20.1-30 \mathrm{~cm}$ in length suggesting smaller fish to be more susceptible to infestation. The highest mean intensity (11.3), however, was recorded during the summer survey for the $20.1-30 \mathrm{~cm}$ length group with as many as 20 parasites per host. This length group in fact recorded the highest mean intensity values for all seasonal surveys, except during spring (Table 4).

Neutraclinostomum intermedialis does indicate some, yet not pronounced, seasonal variations in prevalence and intensity of infestation. This rela- tively small seasonal variation in infestation rates is to be expected in a young, subtropical impoundment where seasonal climatic conditions are not sharply demarcated. Furthermore, comparison of infestation rates amongst different sexes of the host failed to illustrate any noteworthy differences.

Mokgalong (1996) clearly illustrated $A$. rufa to be the definitive host for $N$. intermedialis, with $75 \%$ of the examined hosts from Middle Letaba Dam infested (Table 5). He further reported high infestation values of $N$. intermedialis for this bird (intensity $=$ 7-72 and mean intensity $=35$ ). These values correspond well (prevalence of 50-100\%) if compared with similar data for other water bodies in the Limpopo Province (Mokgalong 1996). The high infestation values of $A$. rufa in Middle Letaba Dam, and the fact that it is one of the most abundant resi- 
TABLE 5 Parasite/host checklist of definitive hosts (piscivorous birds) at Middle Letaba Dam infested with adult members of Clinostomidae

\begin{tabular}{|c|c|c|c|c|c|}
\hline Parasite & Host & $n$ & Prev. & In. & Mi. \\
\hline Neutraclinostomum intermedialis (Lamont) & Anhinga rufa (Daudin) & 44 & 75 & $7-72$ & 35 \\
\hline Clinostomum complanatum (Rudolphi) & $\begin{array}{l}\text { Phalacrocorax lucidus (Lichtenstein) } \\
\text { Phalacrocorax africanus (Gmelin) } \\
\text { Anhinga rufa (Daudin) } \\
\text { Ardea cinerea Linnaeus } \\
\text { Nycticorax nycticorax (Linnaeus) }\end{array}$ & $\begin{array}{l}11 \\
30 \\
44 \\
3 \\
3\end{array}$ & $\begin{array}{l}63 \\
60 \\
96 \\
66 \\
66\end{array}$ & $\begin{array}{l}1-37 \\
1-7 \\
3-190 \\
1-3 \\
2-4\end{array}$ & $\begin{array}{l}11 \\
4 \\
48 \\
2 \\
3\end{array}$ \\
\hline Euclinostomum heterostomum (Rudolphi) & $\begin{array}{l}\text { Phalacrocorax luidus (Lichtenstein) } \\
\text { Phalacrocorax africanus } \\
\text { Anhinga rufa (Daudin) } \\
\text { Ardea cinerea Linnaeus } \\
\text { Ardea melanocephala Anon } \\
\text { Ardea purpurea Linnaeus }\end{array}$ & $\begin{array}{l}11 \\
30 \\
44 \\
3 \\
5 \\
2\end{array}$ & $\begin{array}{l}88 \\
30 \\
80 \\
100 \\
100 \\
50\end{array}$ & $\begin{array}{l}1-21 \\
1-10 \\
1-11 \\
4-6 \\
1-8 \\
1\end{array}$ & $\begin{array}{l}7 \\
6 \\
5 \\
5 \\
5 \\
1\end{array}$ \\
\hline
\end{tabular}

$n \quad=$ number of hosts examined

Prev. = prevalence of infestation (\%)

In. = intensity of infestation

Mi. = mean intensity of infestation

TABLE 6 Comparison of infestation values of Neutraclinostomum intermedialis (Lamont) in Oreochromis mossambicus (Peters) in different water bodies of the Limpopo and Olifants Rivers Drainage Systems—data from Saayman (1986)

\begin{tabular}{|l|l|l|l|l|}
\hline Waterbody & $\boldsymbol{n}$ & Prev. & In. & Mi. \\
\hline Middle Letaba Dam & 177 & 48 & $1-21$ & 4.5 \\
Glen Alpine Dam & 89 & 14.6 & $1-6$ & 2 \\
Luphephe-Nwanedzi Dams & 157 & 10.7 & $1-5$ & 1.4 \\
Nwanedzi River & 66 & 54.6 & $1-8$ & 3.2 \\
Nzhelele Dam & 15 & 7 & 1 & 1 \\
Seshego Dam & 35 & 38 & $1-5$ & 3 \\
Nile Flood Pans & 58 & 62.1 & $1-13$ & 3.5 \\
Piet Gouws Dam & 59 & 35.6 & $1-14$ & 2.8 \\
Lepellane Dam & 114 & 28.9 & $1-6$ & 2.1 \\
Tompi Seleka Fish Station & 25 & 64 & $1-2$ & 1.5 \\
\hline
\end{tabular}

$n \quad$ = number of hosts examined

Prev. = prevalence of infestation (\%)

In. = intensity of infestation

Mi. = mean intensity of infestation

dent fish-eating birds (Olivier, Saayman \& Polling 1991), tend to indicate that intensity of infestation in the intermediate host (O. mossambicus) may well increase drastically in the near future.

Saayman (1986) investigated $N$. intermedialis infestations in $O$. mossambicus in various other water bodies of the Limpopo and Olifants Rivers Drainage Systems in the Limpopo Province (Table 6). Only three of these water bodies (Nile Flood Pans, Nwanedzi River and Tompi Seleka Fish Station) exhibit infestation values comparable to that of Middle Letaba Dam. Values obtained from Tompi Seleka are to be expected as it represents a situation where fish are kept at high densities in production ponds. These ponds were also densely populated with snails, the invertebrate intermediate host for $N$. intermedialis, (no data on the species of the snails are available) and aquatic macrophytes. The ratio of shore to water area in production ponds is far greater than that for impoundments, resulting in enhanced opportunities for released cercariae to locate suitable hosts. Physical conditions in the Nile Flood Pans and pools in the Nwanedzi River are almost similar to the situation at Tompi Seleka and this may explain the high levels of infestation recorded for these two localities.

\section{Clinostomum complanatum (Rudolphi)}

In Middle Letaba Dam only four of the potential fish host species (Table 1) were infested with metacer- 
cariae of C. complanatum (Table 3). In all of the infested hosts the parasites were always found encysted on the peritoneum of visceral organs with an explicit preference for the peritoneum of the ventral surface of the swim bladder. Extremely low prevalence and intensity values were recorded (Table 3).

Saayman (1986) investigated several indigenous fish species from various localities in the Olifants and Limpopo Drainage Systems for C. complanatum infestations. From the numerous hosts investigated, only five species (including Marcusenius macrolepidotus (Peters) which was not encountered in Middle Letaba Dam) were infested (Table 7). From the infested hosts, a total of 1985 parasites were procured with prevalence and intensity values, as given in Table 7, profoundly higher than those recorded for Middle Letaba Dam.

Seven piscivorous birds at Middle Letaba Dam were identified by Mokgalong (1996) as regular final hosts for C. complanatum (Table 5). Although relatively low numbers of birds were examined, the data of Table 5 clearly indicate $A$. rufa as the predominant definitive host for this parasite. Reed cormorants, Phalacrocorax africanus (Gmelin), grey herons,
Ardea cinerea Linnaeus. and black-crowned night herons, Nycticorax nycticorax Linnaeus, seem to act as subsidiary final hosts.

If the results from the present study and that of Saayman (1986) are evaluated, the following important observation needs to be elucidated: S. intermedius and $M$. macrolepidotus seem to be the major intermediate hosts for C. complanatum (Table 7). Both were, however, absent from Middle Letaba Dam at the time of the survey, but $S$. intermedius does occur in the catchment area of the dam (Table 1). It can, therefore, be expected that the latter will colonize the dam at some stage. As the biological requirements for the completion of the life cycle of the parasite are established in the dam, it could well be expected that $S$. intermedius would immediately become infested after colonization.

\section{Euclinostomum heterostomum (Rudolphi)}

During this study, E. heterostomum was recorded regularly, encysted in muscle tissue of the host. The major intermediate host was identified as 0 . mossambicus from which a total of 96 parasites were collected (Table 8). A single male C. gariepinus (to-

TABLE 7 Fish intermediate hosts from various localities in the Olifants (O) and Limpopo (L) Rivers Drainage Systems infested with Clinostomum complanatum (Rudolphi)—data from Saayman (1986)

\begin{tabular}{|c|c|c|c|c|c|}
\hline Host & $n$ & Prev. & In. & Mi. & Locality and drainage system \\
\hline Schilbe intermedius (Rüppell) & 399 & 28.7 & $1-21$ & 3.4 & $\begin{array}{l}\text { Luphephe-Nwanedzi Dams (L) } \\
\text { Nwanedzi River (L) } \\
\text { Glen Alpine Dam (L) } \\
\text { Magalakwena River (L) } \\
\text { Nzhelele Dam (L) } \\
\text { Nile Flood Pans (L) } \\
\text { Ga-Selati River (O) } \\
\text { Olifants River (O) } \\
\text { Letaba Estates (O) }\end{array}$ \\
\hline $\begin{array}{l}\text { Marcusenius macrolepidotus } \\
\text { (Peters) }\end{array}$ & 524 & 54.7 & $1-122$ & 6.7 & $\begin{array}{l}\text { Luphephe-Nwanedzi Dams (L) } \\
\text { Nwanedzi River (L) } \\
\text { Glen Alpine Dam (L) } \\
\text { Nzhelele Dam (L) } \\
\text { Nile Flood Pans (L) } \\
\text { Mohlapitse River (O) } \\
\text { Letaba Estates (O) }\end{array}$ \\
\hline Barbus unitaeniatus Günther & 2 & 50 & 1 & 1.0 & Letaba Estates (O) \\
\hline Barbus toppini Weber & 1 & 100 & 8 & 8.0 & Letaba Estates (O) \\
\hline Chiloglanis pretoriae Van der Horst & 115 & 5.2 & $1-4$ & 2.2 & $\begin{array}{l}\text { Luvhuvhu River (L) } \\
\text { Nwanedzi River (L) } \\
\text { Mohlapitse River (O) }\end{array}$ \\
\hline $\begin{array}{ll}n & =\text { number of hosts examined } \\
\text { Prev. } & =\text { prevalence of infestation (\%) } \\
\text { In. } & =\text { intensity of infestation } \\
\text { Mi. } & =\text { mean intensity of infestation }\end{array}$ & & & & & \\
\hline
\end{tabular}


tal length $=66,3 \mathrm{~cm}$ ), from a sample of 21 specimens examined, collected during the winter survey, was found harbouring nine specimens of $E$. heterostomum. This may suggest that $C$. gariepinus, in extreme cases, can act as a reservoir host.

The data of Table 8 reflect that all length groups of O. mossambicus may become infested with the parasite although it appears as if larger fish (total length longer than $20 \mathrm{~cm}$ ) may be more vulnerable to infestation. No significant seasonal variations in infestation, nor any prevalence amongst different sexes, were observed.

In Middle Letaba Dam it was established that members of the Ardeidae, Phalacrocoracidae and Anhingidae act as final hosts for the adults of $E$. heterostomum (Table 5), the latter firmly attached to the lining of the buccal cavity and oesophagus.
Except for $P$. africanus with a prevalence of $30 \%$, all the other hosts demonstrated higher prevalence values ranging from $50-100 \%$ with intensity values ranging from 1-21. White-breasted cormorants, Phalacrocorax lucidus (Lichtenstein), and $A$. rufa seem to be the major definitive hosts, but, $A$. cinerea, black-headed herons, Ardea melanocephala (Anon), and purple herons, Ardea purpurea Linnaeus, may well prove to be equally or even more important, pending the examination of larger numbers of hosts.

Although clinostomid metacercarial cysts attain a relatively large size, and notwithstanding the relatively high infestation values, it does not appear as if these parasites cause any deleterious affects to semi-adult and/or adult hosts. This observation is supported by Paperna (1980). In fingerlings and

TABLE 8 Seasonal analysis per length group (TL, $\mathrm{cm}$ ) of Oreochromis mossambicus (Peters) for Euclinostomum heterostomum (Rudolphi) infestations in Middle Letaba Dam

\begin{tabular}{|c|c|c|c|c|c|}
\hline Season & $<10 \mathrm{~cm}$ & $10.1-20 \mathrm{~cm}$ & $20.1-30 \mathrm{~cm}$ & $>30 \mathrm{~cm}$ & All size groups \\
\hline \multicolumn{6}{|l|}{ Summer } \\
\hline $\begin{array}{l}\text { Number of hosts examined } \\
\text { Prevalence of infestation } \\
\text { Intensity of infestation } \\
\text { Mean intensity of infestation } \\
\text { Number of parasites collected }\end{array}$ & $\begin{array}{l}39 \\
12.8 \\
1 \\
1 \\
5\end{array}$ & $\begin{array}{l}24 \\
33.3 \\
1-9 \\
2.6 \\
21\end{array}$ & $\begin{array}{l}23 \\
56.5 \\
1-8 \\
2.2 \\
29\end{array}$ & $\begin{array}{l}1 \\
100 \\
5 \\
5 \\
5\end{array}$ & $\begin{array}{l}87 \\
31 \\
1-9 \\
2.2 \\
60\end{array}$ \\
\hline \multicolumn{6}{|l|}{ Autumn } \\
\hline $\begin{array}{l}\text { Number of hosts examined } \\
\text { Prevalence of infestation } \\
\text { Intensity of infestation } \\
\text { Mean intensity of infestation } \\
\text { Number of parasites collected }\end{array}$ & $\begin{array}{l}2 \\
- \\
- \\
- \\
-\end{array}$ & $\begin{array}{l}10 \\
20 \\
1-2 \\
1.5 \\
3\end{array}$ & $\begin{array}{l}3 \\
- \\
- \\
- \\
-\end{array}$ & $\begin{array}{l}- \\
- \\
- \\
-\end{array}$ & $\begin{array}{l}15 \\
13.3 \\
1-4 \\
1.5 \\
3\end{array}$ \\
\hline \multicolumn{6}{|l|}{ Winter } \\
\hline $\begin{array}{l}\text { Number of hosts examined } \\
\text { Prevalence of infestation } \\
\text { Intensity of infestation } \\
\text { Mean intensity of infestation } \\
\text { Number of parasites collected }\end{array}$ & $\begin{array}{l}11 \\
9.1 \\
1 \\
1 \\
1\end{array}$ & $\begin{array}{l}4 \\
- \\
- \\
- \\
-\end{array}$ & $\begin{array}{l}25 \\
36 \\
1-4 \\
2.1 \\
19\end{array}$ & $\begin{array}{l}- \\
- \\
- \\
-\end{array}$ & $\begin{array}{l}40 \\
25 \\
1-4 \\
2 \\
20\end{array}$ \\
\hline \multicolumn{6}{|l|}{ Spring } \\
\hline $\begin{array}{l}\text { Number of hosts examined } \\
\text { Prevalence of infestation } \\
\text { Intensity of infestation } \\
\text { Mean intensity of infestation } \\
\text { Number of parasites collected }\end{array}$ & $\begin{array}{l}18 \\
5.6 \\
1 \\
1 \\
1\end{array}$ & $\begin{array}{l}14 \\
28.6 \\
1-6 \\
3 \\
12\end{array}$ & $\begin{array}{l}3 \\
- \\
- \\
- \\
-\end{array}$ & $\begin{array}{l}- \\
- \\
- \\
-\end{array}$ & $\begin{array}{l}35 \\
14.3 \\
1-6 \\
2.6 \\
13\end{array}$ \\
\hline \multicolumn{6}{|l|}{ All seasons } \\
\hline $\begin{array}{l}\text { Number of hosts examined } \\
\text { Prevalence of infestation } \\
\text { Intensity of infestation } \\
\text { Mean intensity of infestation } \\
\text { Number of parasites collected }\end{array}$ & $\begin{array}{l}70 \\
10 \\
1 \\
1 \\
7\end{array}$ & $\begin{array}{l}52 \\
26.9 \\
1-9 \\
2.6 \\
36\end{array}$ & $\begin{array}{l}54 \\
43.1 \\
1-8 \\
2.2 \\
48\end{array}$ & $\begin{array}{l}1 \\
25 \\
1 \\
1 \\
5\end{array}$ & $\begin{array}{l}177 \\
24.9 \\
1-9 \\
2.2 \\
96\end{array}$ \\
\hline
\end{tabular}


smaller fish species, however, severe infestations are likely to be detrimental. Paperna (1980) reported mortalities amongst very young $(40-60 \mathrm{~mm}) O$. mossambicus, even with intensity values of as low as $3-5$ worms. During the present survey a number of juvenile specimens of $O$. mossambicus infested with $E$. heterostomum showed definite signs of locomotory impairment. Severe infestation with $N$. intermedialis is also likely to cause respiratory inhibition.

Britz, Saayman \& Van As (1984) and Britz, Van As \& Saayman (1984) reported considerable physical and histological damage to the oesophageal mucosa of avian hosts infested with clinostomid worms. This supports earlier reports from Baugh \& Pandey (1969) and Ukoli (1970). The latter author observed that if worms are removed from the oesophageal region of the host, part of the host tissue is torn away, leaving a deep lesion which bleeds freely. The study at Middle Letaba Dam confirmed these observations in almost all infested avian hosts.

\section{ACKNOWLEDGEMENTS}

The authors thank the Department of Development Aid, Premier Food Industries Ltd. and the Research Development and Administration of the University of Limpopo for financial assistance. We also thank the (then) Gazankulu Government for their involvement and support and the Department of Biodiversity, University of Limpopo for infrastructure and technical support.

\section{REFERENCES}

ALLANSON, R.B. \& JACKSON, P.B.N. 1983. Limnology and fisheries potential of Lake PK le Roux. Pretoria: CSIR (South African National Scientific Programmes. Report no. 77).

BAUGH, C.H. \& PANDEY, K.C. 1969. Studies on clinostome metacercariae. I. A restudy of Clinostomum giganticum. Angewandte Parasitologie, 10:211-223.

BRAGG, R.R. 1991. Health status of salmonids in river systems in Natal. I. Collection of fish and parasitological examination. Onderstepoort Journal of Veterinary Research, 58:59-62.

BRITZ, J., SAAYMAN, J.E. \& VAN AS, J.G. 1984. Notes on the morphology of the adult and metacercaria of Clinostomum tilapiae Ukoli, 1966 (Trematoda: Clinostomatidae). Journal of Wildlife Research, 14:69-72.

BRITZ, J., VAN AS, J.G. \& SAAYMAN, J.E. 1984. Anatomy of the metacercaria and adults of Euclinostomum heterostomum (Rudolphi, 1809) (Trematoda: Clinostomatidae). South African Journal of Zoology, 19:91-96.

CHRISTISON, K.W., SHINN, A.P. \& VAN AS, J.G. 2005. Gyrodactylus thlapi n.sp. (Monogenea) from Pseudocrenilabrus philander philander (Weber) (Cichlidae) in the Okavango Delta, Botswana. Systematic Parasitology, 60:165-173.
CRAM, D. 1980. Hidden elements in the development and implementation of marine resource conservation policy. The case of South West Africa/Namibian fisheries, in Resource management and environmental uncertainty, edited by M.H. Glantz. New York: John Wiley and Sons.

ERGENS, R. 1973. Two new species of Gyrodactylus from Clarias lazera (Vermes, Trematoda, Monogenoidea). Revue de Zoologie et de Botanique Africaines, 87:77-80.

FEIZULLAEV, N.A. \& MIRZOEVA, S.S. 1983. Revision of the superfamily Clinostomoidae and analysis of its system. Parasitologiia (Lenin), 17:3-11.

GAIGHER, I.G. 1973. The habitat preferences of fishes from the Limpopo River System, Transvaal and Mozambique. Koedoe, 16:103-116.

GAIGHER, I.G. \& McPOTT, C. 1973. Distribution of fishes in southern Africa. South African Journal of Science, 69:25-27.

GROBLER, J.P. \& MOKGALONG, N.M. 2002. Patterns of genetic heterogeneity in Neutraclinostomum intermedialis (Digenea: Clinostomatidae): geographical and temporal considerations. African Zoolology, 37:55-60.

GROBLER, J.P., MOKGALONG, N.M. \& SAAYMAN, J.E. 1999. Genetic divergence between two clinostomatid fish endoparasites, inferred from allozyme and RAPD data. South African Journal of Zoology, 34:135-139.

HECHT, T. 1985. Recent developments in aquaculture in South Africa: the sharptooth catfish, Clarias gariepinus, in Aquaculture in South Africa, edited by T. Hecht, M. Bruton \& O. Safriel. Pretoria: CSIR (Foundation for Research Development. Report no. 1)

HECHT, T., UYS, W. \& BRITZ, P.J. 1988. The culture of the sharptooth catfish, Clarias gariepinus. Pretoria: CSIR (South African National Scientific Programmes. Report no. 153).

HOCKEY, P.A.R., DEAN, W.R.J. \& RYAN, P.G. 2005. Robert's birds of southern Africa, $7^{\text {th }}$ ed. Cape Town: John Voelcker Bird Book Fund.

KHALIL, L.F. \& MASHEGO, S.N. 1998. The African monogenean gyrodactylid genus Macrogyrodactylus Malberg, 1957, and the reporting of three species of the genus on Clarias gariepinus in South Africa. Onderstepoort Journal of Veterinary Research, 65:223-231.

KHALIL, L.F. \& POLLING, L. 1997. Checklist of the helminth parasites of African fresh water fishes. Pietersburg: Department of Zoology and Biology, University of the North.

LOMBARD, G.L. 1968. A survey of fish diseases and parasites encountered in Transvaal. Newsletter of the Limnological Society of South Africa, 11:23-29.

LUUS-POWELL, W.J., MASHEGO, S.N. \& KHALIL, L.F. 2003. Mormyrogyrodactyus gemini gen. et sp. n. (Monogenea: Gyrodactylidae), a new gyrodactylid from Marcusenius macrolepidotus (Mormyridae) from South Africa. Folia Parasitologica, 50:49-55.

MASHEGO, S.N. 1983. South African monogenetic parasites of the genus Dactylogyrus: new species and records (Dactylogyridae: Monogenea). Annals of the Transvaal Museum, 33: 337-346.

MASHEGO, S.N. 2000. Occurrence of Neodiplozoon polycotyleus Paperna, 1973 (Diplozoidae: Monogenea) in cyprinid fish in South Africa. Onderstepoort Journal of Veterinary Research, 67:153-154.

MOKGALONG, N.M. 1996. A study of the gastrointestinal helminthes of the Phalacrocoracidae and the Anhingidae of the Northern Province, South Africa. Ph.D. thesis, University of the North. 
NOBLE, R.G. \& HEMENS, J. 1978. Inland water ecosystems in South Africa-a review of research needs. Pretoria: CSIR (South African National Scientific Programmes. Report no. 34).

OLIVIER, P.A.S., KRUGER, E.J., VAN DER WAAL, B.C.W., VILJOEN, C., VILJOEN, J.H. \& POLLING, L. 1986. Survey of the distribution of fish in the catchment area of Middle Letaba Dam. Final report. Pretoria: Department of Development Aid.

OLIVIER, P.A.S., SAAYMAN, J.E. \& POLLING, L. 1991. Seasonality and abundance of waterbirds of the Middle Letaba Dam, in A post-impoundment ecological study of the Middle Letaba Dam, Gazankulu, with special reference to its fish production potential, edited by J.E. Saayman \& H.J. Schoonbee. Sovenga, Pietersburg: University of the North.

PAPERNA, I. 1980. Parasites, infections and diseases of fish in Africa. Rome: Food and Agriculture Organization of the United Nations (CIFA Technical Paper, no. 7).

POLLING, L., MOKGALONG, N.M. \& SAAYMAN, J.E. 1983. The fishes of the Limpopo and Olifants River tributaries (Limpopo drainage basin). Part $V$. Annotated checklist of the fishes of the Luvhuvhu sub-system, Limpopo River system (University of the North Series A, 30:1-13).
ROODE, M.C. 1978. Harvesting of freshwater fish from natural resources. A marketing experiment conducted in the Transkei. Fish Farmer, 20:2-12.

RÓZSA, L., REICZIGEL, J. \& MAJOROS, G. 2000. Quantifying parasites in samples of hosts. Journal of Parasitology, 86: 228-232.

SAAYMAN, J.E. 1984. Supportive biological disciplines for aquaculture development with special reference to aquaparasitology. Fish Farmer, 34:9-10.

SAAYMAN, J.E. 1986. The limnology of waterbodies of National States of North-east Transvaal. Final report. Pretoria: Department of Development Aid.

SAFRIEL, O. \& BRUTON, M.N. 1984. Aquaculture in South Africa: A cooperative research programme. Pretoria: CSIR (South African National Scientific Programmes. Report no. 89).

SKELTON, P. 2001. A complete guide to the freshwater fishes of southern Africa. Cape Town: Struik Publishers.

UKOLI, F.M.A. 1970. On the adhesive mechanisms of Apharyngostrigea (Apharyngostrigea) simplex (Johnston, 1904) and Clinostomum tilapiae (Ukoli, 1966). Nigerean Journal of Science, 4:77-88. 